heterogeneous semi-Markov model was determined and then validated; the initial data set was randomly split into two groups: two thirds (450 patients) to build the model and one third (226 patients) to validate it. The model defined five states: ICU admission, first simple infection, first complicated infection, death, and discharge from the ICU. Transitions between these states determined nine different events. The global model of patient histories can be divided into nine survival models, each corresponding to one of these events. The possible events from a given state were considered to be competing. Since many risk factors induced nonproportional hazard functions, piecewise exponential models were used to model event occurrence. The effect of continuous covariates on hazard functions has been described with a nonparametric method that enables nonlinear relations to be shown.

Among other things, the model allows patients' postadmission histories to be predicted from data available at ICU admission. The bootstrap estimator of the attributable risk of death due to simple or complicated nosocomial infections is $44.2 \%$ (95\% confidence interval, 26.0-61.6). They were also able to characterize the most highly exposed patients, those who comprise the high-risk group on whom prevention efforts must be focused.

FROM: Escolano S, Golmard JL, Korinek AM, Mallet A. A multi-state model for evolution of intensive care unit patients: prediction of nosocomial infections and deaths. Stat Med 2000;19:3465-3482.

\section{Testing Disinfectant Efficiency on Pseudomonas Biofilm}

Wirtanen and colleagues from VTT Biotechnology and Food Research, Espoo, Finland, conducted studies on the effect of disinfectants on biofilms. Biofilms of the gram-negative bacteria Pseudomonas aeruginosa and Pseudomonas fragi were grown on stainless steel surfaces (AISI 304, 2B) for 4 days in slime broth. These biofilms were treated with four commercial disinfectants. The disinfectants were alcohol-based, tenside-based, peroxidebased, and chlorine-based products, covering most disinfectant types used in the food industry. The effects of the disinfectants on the bacterial cells were first investigated in suspension using the permeabilization test, which is based on fluorescence assessment of hydrophobic 1-Nphenylnaphtylamine. The surfaces covered with disinfectanttreated biofilms were investigated using conventional cultivation, impedimetry, and epifluorescence microscopy in combination with image analysis of preparations stained with the DNA stain acridine orange and with the metabolic indicator system CTC-DAPI.

The results showed that the tenside-based and peroxide-based disinfectants permeabilized the cells in suspension. The overall biofilm results showed that, of the agents tested, the peroxide-based and chlorine-based disinfectants acted most effectively on cells in biofilms.

FROM: Wirtanen G, Salo S, Helander IM, MattilaSandholm T. Microbiological methods for testing disinfectant efficiency on Pseudomonas biofilm. Colloids Surf $B$ Biointerfaces 2001;20:37-50.

\section{New Oligosaccharide Antibiotic for Gram-Positive Nosocomial Pathogens}

Gram-positive bacteria are increasingly found to be causative pathogens in nosocomial infections, and the occurrence of vancomycin resistance in enterococci, as well as staphylococci, has prompted Kropec and colleagues from the Institute of Environmental Medicine and Hospital Epidemiology, University Hospital Freiburg, to conduct an investigation of alternative antimicrobial agents active against these strains. Everninomycin, a new oligosaccharide antibiotic, has excellent in vitro activity against grampositive bacteria, including those resistant to vancomycin. However, avilamycin, a related compound, has been used in Europe as a growth promoter in animal food for years, and concern has been raised that cross-resistance in clinical isolates may arise.

They studied a collection of 268 nosocomial grampositive isolates from ICU patients with nosocomial pneumonia, urinary tract infection, and sepsis, using standard in vitro susceptibility testing. All species tested were sensitive to everninomycin. Furthermore, no difference could be observed between methicillin-resistant and methicillinsensitive Staphylococcus aureus or between Enterococcus faecium and Enterococcus faecalis.

These results suggest that everninomycin is a promising antibiotic for the treatment of nosocomial infections in ICU patients and that the use of a related substance as an additive in animal food has not yet promoted resistance in clinical isolates

FROM: Kropec A, Frank U, Jonas D, Thriene W, Schmidt-Eisenlohr E, Daschner FD. In vitro susceptibility to everninomycin of gram-positive nosocomial pathogens isolated from intensive care units in Germany. Chemotherapy 2001;47:15-18. 


\section{Program}

The program will be held May 12-15, 2001 at the Jacksonville Hilton and Towers at Jacksonville, FL. Timothy W. Lane, M.D., Julie Gerberding M.D., and Gina Pugliese, R.N., M.S., will co-chair the program. This program, developed by the Society for Healthcare Epidemiology of America (SHEA), and the Centers for Disease Control and Prevention (CDC), is intended for infectious disease fellows and new hospital epidemiologists. It emphasizes hands-on exercises in which participants work in small groups to detect, investigate, and control epidemiological problems encountered in the hospital setting. These work sessions are supplemented with lectures and seminars covering fundamental aspects of hospital epidemiology and surveillance, epidemic investigation, transmission and control of nosocomial infections, disinfection and sterilization, employee health, isolation systems, regulatory compliance, and quality improvement.

\section{Who Should Attend}

You should attend if you are a hospital epidemiologist or an infection control practitioner or if you are looking for a course that will provide you with the most current information concerning infection control practices and epidemiological methods in health care. This fundamental program will provide you with opportunities to find solutions to real situations that will occur in the hospital setting. Intensive problem solving sessions are supplemented with lectures and seminars presented by leading authorities.

\section{Jonathan Freeman Scholarships}

Seven Jonathan Freeman Scholarships in the amount of $\$ 1,000$ each will be awarded to infectious disease fellows for the program to defray the special course fee for fellows of $\$ 400$ and expenses incurred in attending the training program.

Interested fellows must submit a letter of no more than one page describing why they would like to have additional training in hospital epidemiology. A letter from the fellow's program director outlining the applicant's qualifications and suitability for the course also is required. The deadline for receipt of scholarship applications for the course is April 23, 2001. The SHEA Educational Activities Committee will select the scholarship recipients based on review of these letters. Winners will be notified in late April.

\section{Nominations}

Please send scholarship applications to: Timothy W. Lane, M.D.

c/o The Society for Healthcare Epidemiology of America 19 Mantua Road

Mt. Royal, NJ 08061

\section{Fees}

Individual Registrants $\$ \$ 525$

Fellows in Infectious Disease $\$ \$ 400$

\section{Credits}

The Society for Healthcare Epidemiology of America (SHEA) is accredited by the Accreditation Council for Continuing Medical Education to sponsor continuing medical education for physicians.

The Society for Healthcare Epidemiology of America designates this continuing education activity for up to 23 hours in Category 1 of the Physician's Recognition Award of the American Medical Association.

\section{General Course Information}

Information regarding the schedule, hotel and travel accommodations, discount airfare, and course fees are available from SHEA (856) 423-7222. Note that application for a scholarship does not constitute enrollment in the program. This must be done separately.

Scholarship Awards provided in part by an educational grant from Pfizer Pharmaceuticals and Wyeth Ayerst Research.

\section{Society for Healthcare Epidemiology of America Seeks Journal Editor}

The Society for Healthcare Epidemiology of America is seeking candidates for the position of Editor for Infection Control and Hospital Epidemiology (ICHE). The Editor of ICHE will chair the editorial advisory board and supervise the editorial office and the editorial staff, including a managing editor and administrative support; will supervise the editorial content and substance of the Journal; will serve as a decision maker in situations involving manuscripts suitable for publication; will serve as the Society's liaison with the publisher and manage the services to be provided under contractual agreement with the publisher and assure that services are provided in a manner that promotes ICHE's integrity and the Society's professional reputation; will promote communication among the many individuals involved in the publication; will propose innovation in the Journal in content, emphasis, and form; will represent the Journal at meetings with organizations and individuals interested in ICHE; will attend Board of Directors, Publication Committee, and Editorial Board meetings as necessary and provide reports on the progress and activities of the Journal.

The candidate will begin his or her term at a mutually agreed upon date sometime in the first quarter of 2001 and will serve for a term of 5 years. At the end of the 5-year term, the Editor may be reappointed for an additional 5-year term without a competitive search.

To apply, please forward a letter of application stating your interest and qualifications, including personal publication experience, editorial experience, special training, computer technology, commitment of support from your institution, and membership in SHEA. Please include current curriculum vitae. Applications should be sent to John Sellick, DO, SHEA Publications Committee Chair, 19 Mantua Rd, Mt Royal, NJ 08061. For further information regarding the position, please contact Stephanie Dickinson, SHEA Executive Director, at 856-423-0087 or sheahq@talley.com. 